\title{
SOCIOLOGICAL SURVEY OF THE BUSINESS OF KARDZHALI REGION BASIC FACTORS FOR CHOOSING A LOCALIZATION FROM THE COMPANIES
}

\author{
T. Manolov* \\ Department “Regional Development”, Faculty of Economics, Trakia University, Stara Zagora, Bulgaria
}

\begin{abstract}
Having in mind the variety of possibilities for development of a successful business, the strategic positioning depends of different factors which have direct impact on the localization of the company. In 2014 a local research was made. The objectives of this research are to identify the issues for choosing business localization, and to recommend good advices for improvement of the business environment. The research was carried out in Kurdzhali district among 150 companies. For the research a preliminary developed questioner card was used which contains four groups of questions: 1. Characteristics of the company, 2. Assessment of the factors for localization, 3. Assessment of the basic infrastructure and institutions of the region, 4. Problems related with the choice for localization and the desire for business movement. The collected date has been worked up with SPSS software program.
\end{abstract}

Key words: Regional development; Business localization; Factors and conditions;

\section{INTRODUCTION}

TARGET GROUPS, APPROACH AND METHODOLOGY FOR THE REALIZATION OF THE ACTIVITIES During 2014, as a part of a dissertation named "Examination of the territorial localization of the business of Kardzhali region from "Regional development" desk of the Thracian University"', a sociological survey was carried out among companies from Kardzhali region.

The overall object of the survey, was to examine the main reasons and regularities which lead to the decision of the companies from Kardzhali region, where to settle their economic structures. Several tasks are needed to be carried out in order to fulfill the overall objective which, are related with the territorial localization of the companies from Kardzhali region. Therefore the main tasks of the sociological survey are as follows:

$>\quad$ To analyze the profile of the investigated companies;

$>\quad$ To investigate the assessment of the companies for their main localization factors and conditions;

$>\quad$ To investigate the assessment of the companies about some of their localization factors in Kardzhali region.

*Correspondence to: Tenyo Nikolov Manolov, Bulgaria, Plovdiv, 47, Bul. Maritza, Tel:+359888809977,E-Mail: t.manolov@mail.bg
The scope of this survey is defined by the economic interests and motives of the entrepreneurs from Kardzhali region to organize their business in this region. The main thesis is, that the decision for territorial localization of a business in Kardzhali region is based on a classic economic decisions for optimization of the economic functioning of the company as decreasing of the expenditures, increasing the profit, nearest point to international markets, but not on a sociological factors as ethic structure of the population.

The methodology of the survey includes traditional and contemporary methods for analyses and assessment. In use are:

$>\quad$ Describing method;

$>\quad$ Comparative statistical and sociological analysis;

$>\quad$ Inductive and deductive method and systematic analysis.

For the objectives of this sociological survey, an extract consists of 149 companies from Kardzhali region was used. The extract was based on the following indicators: authenticity, size and volume.

The following representatives from the target groups were included in the survey:

- $\quad$ Private personnel

- Ltd's

- $\quad$ joint-stock companies;

- OTHERS 
Approach and methodology for the realization of the activities.

Basic steps:

1. Design of the survey: choice and description of the examination approach, localization of the recourses;

2. Preparing the methodology of the survey;

3. Defining the characteristics of the methods for collection and analyzing of the information. The number of the questions from the inquiry card is defined by three main factors: the objectives of the sociological survey, the size of the topics, the maximum time needed to fill in the inquiry cards.

Territorial scope of the survey: - Kardzhali region.

Objects of the survey are entrepreneurs from all economic sectors, municipality administrations and etc.

Basic method for collection of information: interviews "face to face" carried out by inquirers.

\section{REPRESENTATIVE EXTRACT}

For this sociological survey, an extract consists of 149 companies from the target groups is used. The summarized data is shown as tables and graphics.

Method for forming - The volume of the extract consists of 150 units. In order to represent different by size and type of business companies, the first 20 biggest companies from different business sectors are selected which have biggest incomes for 2011. After that from the rest companies, based on a casual principal, up to 20 companies are drafted in accordance with their business share. The survey was carried out on a two level nests extract for the selection of the 149 companies. The nests are as follows:

$$
\begin{array}{ll}
> & \text { Kardzhali Municipality }-53 \text { фирми } \\
> & \text { Ardino Municipality }-19 \\
> & \text { Dgebel Municipality }-17 \\
> & \text { Korkovo Municipality }-15 \\
> & \text { Krumovgrad Municipality }-10 \\
> & \text { Momchilgrad Municipality }-22 \\
& \text { ChernoocheneMunicipality }-13
\end{array}
$$

Method for registration of the information direct standardized interview, where is possible in the central offices of the companies.
Maximum size of the mistake in 50\% shares и $95 \%$ guaranteed probability - \%. CHECKING OF THE INQUIRY CARDS: Firstly, the methodology consists of technical and logical check of the filled inquiries. It also consists of $20 \%$ checks by phone calls, and a full check if serious findings appeared in the work of the inquirers.

The inquiry card (with a total of 30 questions) consists of several basic group of questions:

Basic data for the company - legal form, year of establishment, localization, economic branch, economic results for the last 5 years, number of employees, nationality and etc.;

$>\quad$ Factors and conditions for choosing the concrete municipality or dwelling place for the localization of the company.

$>$ Assessment of the infrastructure, administration, human resources

$>\quad$ Contentment of the chosen localization

$>\quad$ Multicultural structure, relations between the ethic groups and etc.

- The inquiry card which was prepared for the entrepreneurs, consist of questions from different types - open and closed questions, multiple choice questions. The diversity of the type of the questions, allows the companies to express freely their opinion and guarantees adequate and reliable results to be received from the survey.

The questions from the inquire card are arranged on the base of their logical sequence:

1. Basic data for the company;

2. Factors and conditions for choosing the localization of the company;

3. Assessment of the infrastructure, administration, human resources;

4. Contentment of the chosen localization;

5. Multicultural structure, relations between the ethic groups and etc.

\section{TOPIC 1: OVERALL ASSESSMENT OF THE CONTENTMENT FROM THE BUSINESS LOCALIZATION}

Do the companies are satisfied or not satisfied from the chosen localization? Do they have problems with the localization and which are these problems? Does the concrete entrepreneur have the intention to move in another region? Fro the survey, we receive the following answers to these questions:

Table 1. Contentment of the chosen localization

\begin{tabular}{|l|c|}
\hline Contentment of the chosen localization: & Answers \% \\
\hline Rather YES & 97 \\
\hline Partly & 1 \\
\hline Rather NO & 2 \\
\hline I cannot say & 0 \\
\hline TOTAL: & 100,0 \\
\hline
\end{tabular}


The answers of the question astonishes with the unconditional contentment of the chosen localization among the entrepreneurs with $97 \%$ of yes.
It is not a surprise that such high rate of overall contentment form the chosen localization, leads to a very low rate for the willingness to remove the company in another localization.

Table 2. Willingness for removing in another region

\begin{tabular}{|l|c|}
\hline Willingness for removing in another region & Answer \% \\
\hline Rather YES & 3,4 \\
\hline Possible establishment of a branch & 14,0 \\
\hline Rather NO & 80,5 \\
\hline Possible closure of the company & 2 \\
\hline TOTAL: & 100,0 \\
\hline
\end{tabular}

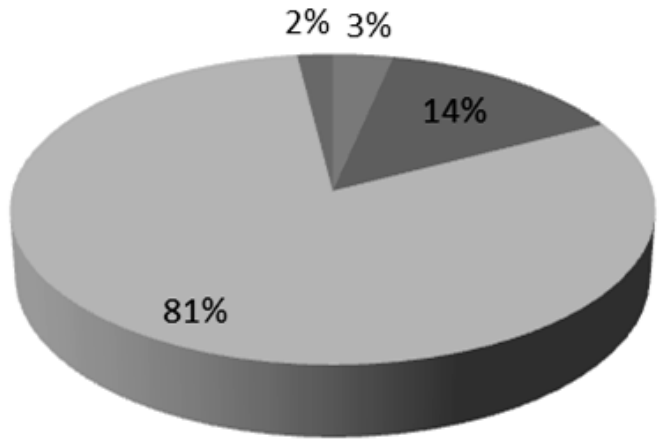

Rather YES

Possible establishment of a branch

Rather NO

Possible closure of the company

Diagram 1. Willingness for removing in another region

Again only $3 \%$ of the companies are thinking for possible movement in another region, and with which they express their frustration from the localization. It is obvious that this is very small part of the business in Kurdzhali region. But this doesn't mean the entrepreneurs from the region do not face problems related to that they are doing business in this region. They express their frustration on the base that there is a lack of clear regional strategy for development. Another reason is the week overall regional market.

Table 3. Basic problems with the localization

\begin{tabular}{|l|c|}
\hline Basic problems with the localization & Answer $\%$ \\
\hline Unclear strategy for regional development & 21,5 \\
\hline Bad infrastructure & 2,7 \\
\hline Unattractive sector & 10,7 \\
\hline Bad human resources & 8,1 \\
\hline Weak local market & 14,1 \\
\hline Bad communication with the local authorities & 1,3 \\
\hline Do not have local problems, the problems are on national level & 41,6 \\
\hline TOTAL: & 100,0 \\
\hline
\end{tabular}

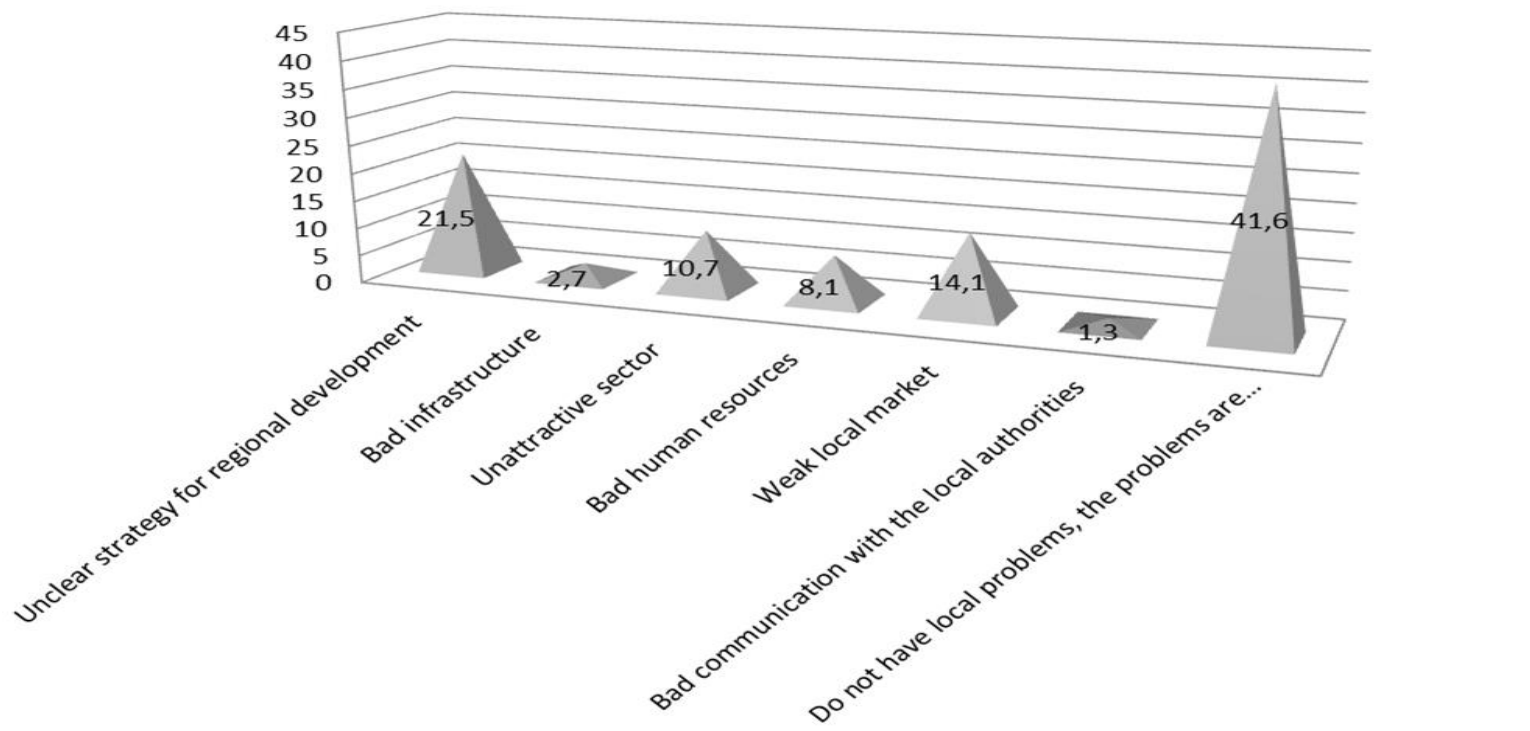


Diagram 2. Basic problems with the localization

CHARACTERISTICS OF THE

INQUIRED TOTALITY

Based on their legal form, the inquired companies are divided as follows:

Private personnel $-45 \%$;

Ltd's $-\mathbf{5 1 \%}$

joint-stock companies $-4 \%$.

By the year of establishment the distribution is:

Table 4. Companies - by period of establishment

\begin{tabular}{|c|c|c|}
\hline Period of establishment & Number of companies & Percentage \\
\hline $1990-2006$ & 119 & 79,87 \\
\hline $2007-2010$ & 27 & 18,12 \\
\hline $2011-2014$ & 3 & 2,01 \\
\hline & 149 & 100 \\
\hline
\end{tabular}

Localization of the company (the examination is made only by municipality level not by a dwelling place):

Table 5. Companies - by municipality

\begin{tabular}{|c|c|c|}
\hline Municipality & Number of companies & Percentage \% \\
\hline Ardino & 19 & 12,75 \\
\hline Dgebel & 17 & 11,41 \\
\hline Kirkovo & 15 & 10,07 \\
\hline Kurdzhali & 53 & 35,57 \\
\hline Krumovgrad & 10 & 6,71 \\
\hline Momchilgrad & 22 & 14,77 \\
\hline Chernoochene & 13 & 8,72 \\
\hline TOTAL: & 149 & $100 \%$ \\
\hline
\end{tabular}

Most of the inquired companies are from the "Producing industry" and the "Trade. Repairing cars and motorcycle industry" followed by "Building industry" and
Established during the period of 1990$2006-\mathbf{8 0 \%}$

Established during the period of 2007$2010-\mathbf{1 8 \%}$

$2014-2 \%$

Established during the period of 2011-
"Agriculture". Based on one of the most important characteristic using for analysis branches, the companies are divided as follows:

Table 6. List of inquired companies - by branches

\begin{tabular}{|l|c|c|}
\hline INQUIRED COMPANIES - BY BRANCHES & NUMBERS & percentage \% \\
\hline Agriculture & 16 & 41 \\
\hline Gaining Industry & 66 & 38 \\
\hline Producing Industry & 2 & 1,4 \\
\hline Energy producing industry .... & 10 & 6,7 \\
\hline Building Industry & 39 & 26 \\
\hline Trade. Car repairing industry & 4 & 4,7 \\
\hline Transport, logistic and post & 7 & 2,7 \\
\hline Hotels and restaurants & 4 & 0,7 \\
\hline Information and creation .... & 1 & 1,4 \\
\hline Real estates & 2 & 0,7 \\
\hline Vocational training and studies. & 1 & $100 \%$ \\
\hline Others & 149 & \\
\hline TOTAL: & & \\
\hline
\end{tabular}


- Agriculture

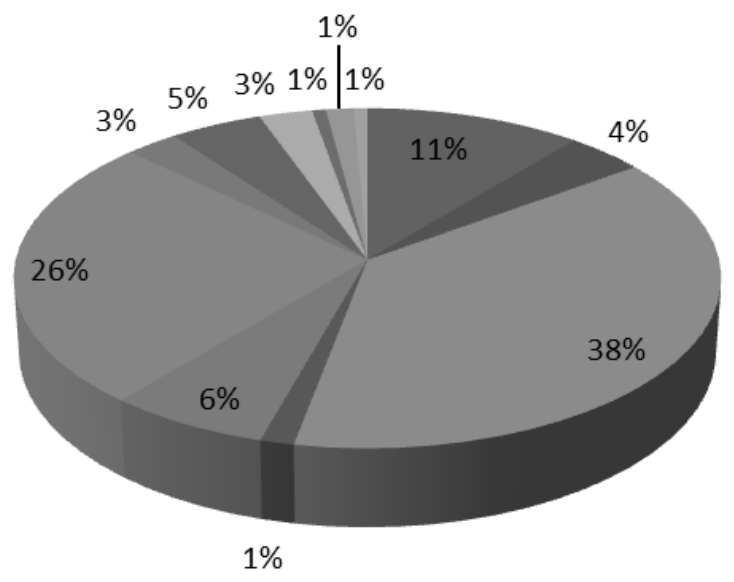

- Gaining Industry

- Producing Industry

— Energy producing industry ....

Building Industry

- Trade. Car repairing industry

- Transport, logistic and post

- Hotels and restaurants

Diagram 3. Inquired companies - by branches

The economic results of the inquired companies for the last 5 years are shown on the table below. As a whole, they could be summarized as very good. Only $3 \%$ of the companies declared loses for more than one year, except 2010 and 2011 (obviously this is the peek of the economic crises for the region) when we have accordingly 9 and $10 \%$ with loses.

Table 7. Distribution among the companies based on their economic result for the last 5 years - in percentages:

\begin{tabular}{|l|c|c|c|c|c|}
\hline & $\begin{array}{c}\text { Result } \\
2008\end{array}$ & $\begin{array}{c}\text { Result } \\
2009\end{array}$ & $\begin{array}{c}\text { Result } \\
2010\end{array}$ & $\begin{array}{c}\text { Result } \\
2011\end{array}$ & Result 2012 \\
\hline Profit & 94 & 94 & 89 & 89 & 92 \\
\hline Zero & & 1 & 1 & 1 & 5 \\
\hline Loses & 3 & 3 & 9 & 10 & 3 \\
\hline Not declared & 3 & 2 & 1 & & 100 \\
\hline TOTAL: & 100 & 100 & 100 & 100 & 100 \\
\hline
\end{tabular}

Most of the inquired companies are micro and small sized $-49 \%$ and $39 \%$ or $88 \%$ as a whole.
The distribution based on the number of employees is as followed:

Table 8. Distribution of the companies based on the number of employees.

\begin{tabular}{|c|c|c|}
\hline Employees & Number of companies & percentage \\
\hline Up to 9 & 73 & 48,99 \\
\hline $10-49$ & 58 & 38,93 \\
\hline $50-250$ & 12 & 8,05 \\
\hline above 250 & 6 & 4,03 \\
\hline & 149 & 100,00 \\
\hline
\end{tabular}

$90 \%$ of the companies are owned by Bulgarians, $10 \%$ have mixed owner (Bulgarians and Greeks or Turkish foreigners). Data for the mixed companies could be seen further in the survey report.

The interviews were made mainly with the owner or with the official representatives of the companies $(59 \%)$ or with other managers (as chief accountant for example) $-29 \%$.
There are $10 \%$ interviews with ordinary employees.

\section{TOPIC 2: FACTORS FOR CHOOSING A LOCALIZACION}

Choosing a territorial localization of a business, has become a huge research question for the last 20 years because of different factors. The actuality and the significant of this 
problem consists of that the development of the individual regions of the country is running with different speed and cover different by structure and market interest economic companies.

From this point of view, it is necessary to see what kind of forms for decision making are put in place when we have to choose a localization for a business, and what are the motives of the entrepreneurs to follow defined economical logic for localization and organization of a new business, of a developing business or are net of branches of shops, distribution stores, and others.

It is appropriate, such complex researches to be made in interesting regions like Kurdzhali. There the traditional factors for choosing a localization like infrastructure, human recourse qualification, nearness to foreign markets (Greece and Turkey) are combined with ethical origin, language advantages (disadvantages), for the employers and other sociological factors.
The focus of the survey is exactly upon the factors and the conditions for choosing a localization (region, municipality, dwelling place) by the companies from Kurdzhali region. Question 9 (probably the central question of the survey) requires from the inquired to arrange by importance the factors and conditions for choosing a concrete municipality (dwelling place) for localization of the company. but this thematic field could be examine by comparing with the answers of other questions from the survey, for example $10,11,12,13$ with question 9 , and also with the questions related with the overall contentment from the location with the willingness for eventual movement (remaining).

Firstly the distribution of the answers of the question for the importance of the factors and the conditions for choosing a concrete municipality (dwelling place) for localization of the company.

Table 9. Factors and conditions for choosing a localization

\begin{tabular}{|l|c|c|}
\hline Factors and conditions : & numbers & Percentage \\
\hline Geographic conditions & 38 & $25,50 \%$ \\
\hline Presence of recourses & 39 & $26,17 \%$ \\
\hline Number and density of the population & 17 & $11,41 \%$ \\
\hline Favorable age structure & 35 & $23,49 \%$ \\
\hline Qualified human recourses & 59 & $39,60 \%$ \\
\hline Relatively low price for the human recourses & 76 & $51,01 \%$ \\
\hline Land with favorable price & 21 & $14,09 \%$ \\
\hline Branch structure and organization & 29 & $19,46 \%$ \\
\hline Technical infrastructure & 32 & $21,48 \%$ \\
\hline Social infrastructure & 23 & $15,44 \%$ \\
\hline Big sales potential & 20 & $13,42 \%$ \\
\hline Easy accessible transport centers & 19 & $12,75 \%$ \\
\hline Nearness to connected companies & 18 & $12,08 \%$ \\
\hline Low number of competitors & 14 & $9,40 \%$ \\
\hline Presents of institutions & 12 & $8,05 \%$ \\
\hline Low domestic taxes & 12 & $8,05 \%$ \\
\hline Local measures for business supporting & 12 & $8,05 \%$ \\
\hline Possibilities for חЧП & 2 & $1,34 \%$ \\
\hline Easy access to financial services & 1 & $0,67 \%$ \\
\hline Presents of universities and other schools & 2 & $1,34 \%$ \\
\hline Strategies and plans for regional development & 9 & $6,04 \%$ \\
\hline Good social climate & 5 & $3,36 \%$ \\
\hline Personal argumentation of the owner & 49 & $32,89 \%$ \\
\hline Other & 1 & $0,67 \%$ \\
\hline
\end{tabular}

(the arrangement is made by the first 5 factors ranked by each inquired )

Many of the factors are pointed as significant from the inquired but firstly we will show the first five of them. And these are:

\author{
$>\quad$ Relatively low price for the human \\ recourses \\ $>\quad$ Presence of human recourses with \\ the necessary qualification \\ $>\quad$ Personal argumentation of the \\ owner
}




\section{in the region}

Geographical and environmental

conditions.

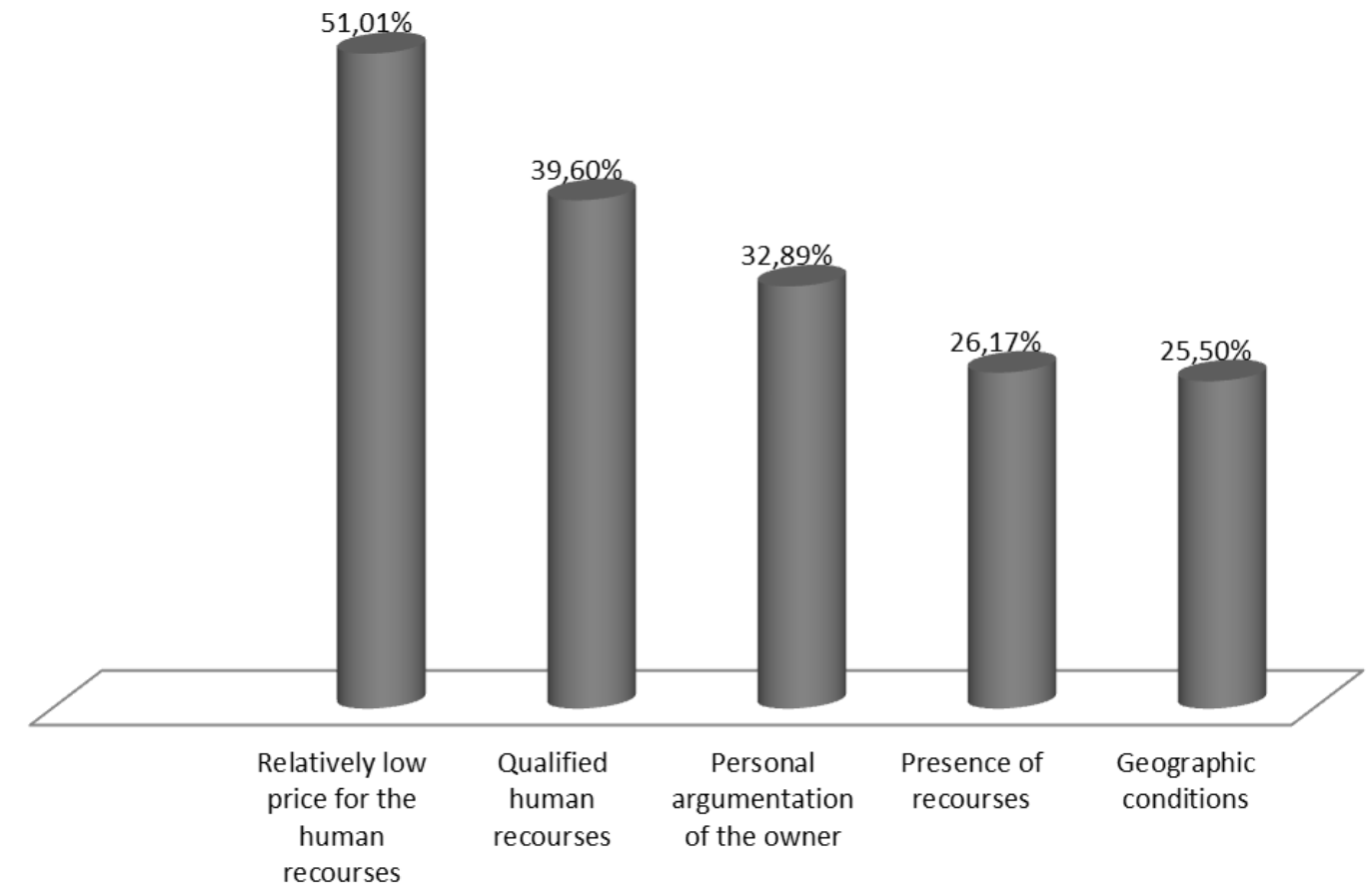

Diagram 4. Major factors for choosing a localization

These factors will be analyzed later more deeply in relation with other answers given by the inquired entrepreneurs.

But we have to point out other factors and conditions, which have significance for choosing a localization from the Kurdzhali's business. These are for example: population

Favorable age structure of the \# Branch structure and organization of the regional economy

* Technical infrastructure

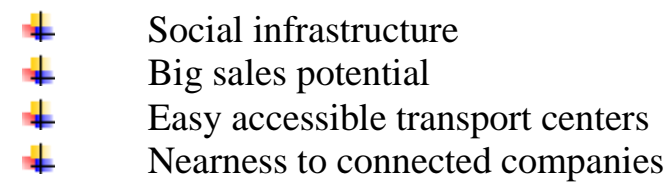

For 20 to 35 from the inquired significant influence also have:

$\begin{array}{lll}\checkmark & \text { Low number of competitors } & \\ \checkmark & \text { Presents of institutions } & \\ \checkmark & \text { Low rate of the local taxes } & \\ \checkmark & \text { Local measures for business } \\ \text { supporting } & \end{array}$

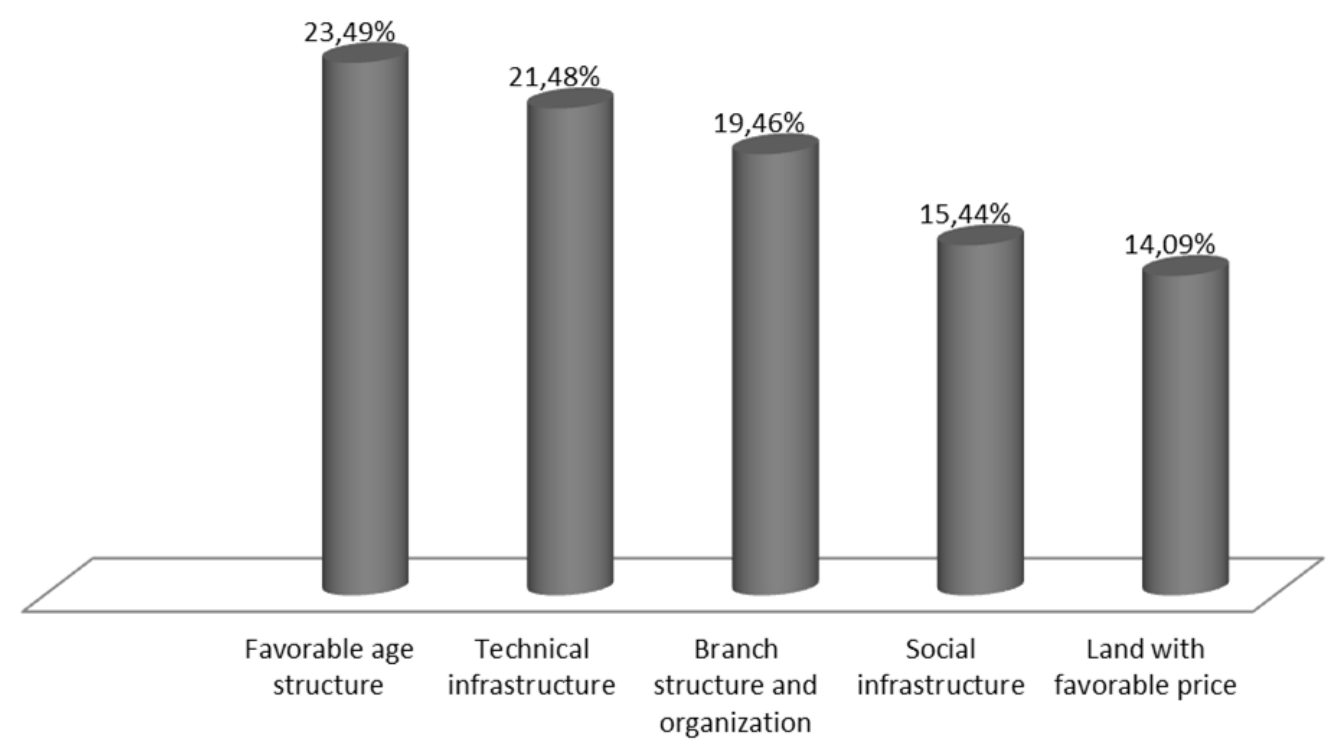




\section{CROSS TABLES.}

Table 10. Correlation: contentment from the localization / year of establishment

\begin{tabular}{|c|c|c|c|}
\hline \multicolumn{2}{|c|}{ Correlation: contentment from the localization / year of establishment } \\
\hline Year / & Contented & Partially & Not contented \\
\hline $1990-2006$ & $97 \%$ & $1 \%$ & $2 \%$ \\
\hline $2007-2010$ & $100 \%$ & 0 & 0 \\
\hline $2011-2014$ & $100 \%$ & 0 & 0 \\
\hline
\end{tabular}

Table 11. Cross-table: municipalities / domestic problems

\begin{tabular}{|c|c|c|c|c|c|c|c|c|}
\hline $\begin{array}{l}\text { Municipality / } \\
\text { problems }\end{array}$ & $\begin{array}{l}\text { Unclear } \\
\text { strategy }\end{array}$ & $\begin{array}{c}\text { Road } \\
\text { infrastructure }\end{array}$ & $\begin{array}{c}\text { Unfavorable } \\
\text { sector }\end{array}$ & Human factor & Weak marke & $\begin{array}{l}\text { Communicatid } \\
\text { with the loca } \\
\text { authorities }\end{array}$ & $\begin{array}{c}\text { Problems } \\
\text { only on } \\
\text { hational leve }\end{array}$ & total: \\
\hline Ardino & $15,79 \%$ & $10,53 \%$ & $10,53 \%$ & $15,79 \%$ & $31,58 \%$ &, $00 \%$ & $15,79 \%$ & 100 \\
\hline Dgebel & $35,29 \%$ & 0 & $5,88 \%$ & $5,88 \%$ & $17,65 \%$ & 0 & $35,29 \%$ & 100 \\
\hline Kirkovo & $40,00 \%$ & 0 & $26,67 \%$ & $6,67 \%$ & $13,33 \%$ & $6,67 \%$ & $6,67 \%$ & 100 \\
\hline Kurdzhali & $24,53 \%$ & 0 & $9,43 \%$ & $5,66 \%$ & $11,32 \%$ & & $49,06 \%$ & 100 \\
\hline Krumovgrad & $10,00 \%$ & $10,00 \%$ & $10,00 \%$ & $30,00 \%$ & 0 & 0 & $40,00 \%$ & 100 \\
\hline Momchilgrad & $9,09 \%$ & $4,55 \%$ & 0 & 0 & $18,18 \%$ & $4,55 \%$ & $63,64 \%$ & 100 \\
\hline Chernoochene & $7,69 \%$ & 0 & $23,08 \%$ & $7,69 \%$ & 0 & & $61,54 \%$ & \\
\hline
\end{tabular}

The cross-table gives us the possibility to notice immediately the regularities:

In the towns like Kurdzhali and Momcchilgrad, the share of the answerers who do not have specific local problems but only such from national significance, is extremely high -52 to $64 \%$. On the other side in Kirkovo this percentage is $6 \%$ and in Ardino is $20 \%$.
$30 \%$ from Ardino complain of "week market" but this share is too small in Kurdgzhali (9\%) and Krumovgrad (0\%).

The small municipalities complain of unclear local strategy, and the citizens of Krumovgrqad - of the human factor.

Table 12. Cross-table: economic branches / local problems

\begin{tabular}{|l|c|c|c|c|}
\hline $\begin{array}{l}\text { COMPANIES BY } \\
\text { BRANCHES }\end{array}$ & $\begin{array}{c}\text { Unattractiveness } \\
\text { of the sector }\end{array}$ & Weak market & $\begin{array}{c}\text { Communication } \\
\text { with the local } \\
\text { administration }\end{array}$ & $\begin{array}{c}\text { Problems on } \\
\text { national level }\end{array}$ \\
\hline Agriculture & $25,00 \%$ & $6,25 \%$ & $0 \%$ & $25,00 \%$ \\
\hline Gaining industry & $33,33 \%$ & $16,67 \%$ & $0 \%$ & $16,67 \%$ \\
\hline Producing Industry & $10,71 \%$ & $17,86 \%$ & $3,57 \%$ & $30,36 \%$ \\
\hline Строителство & $10,00 \%$ & $10,00 \%$ & $0 \%$ & $70,00 \%$ \\
\hline Trade; car repairing & $5,13 \%$ & $10,26 \%$ & $0 \%$ & $64,10 \%$ \\
\hline Transport, store and posts & $0 \%$ & $0 \%$ & $0 \%$ & $50,00 \%$ \\
\hline Hotels and restaurants & $14,29 \%$ & $14,29 \%$ & $0 \%$ & $42,86 \%$ \\
\hline Other & & & & \\
\hline TOTAL (average): & $10,74 \%$ & $14,09 \%$ & $1,34 \%$ & $41,61 \%$ \\
\hline
\end{tabular}

With red are marked the figures, which show significant deviations from the average rates up or down.

And so, regarding the problem "Unattractiveness of the sector" the companies from Agriculture and Gaining industry are much more (almost two times) anxious from the average rates for all the branches. Those from branch "Trade" practically have no complains regarding to such problem (only $5 \%$ as $14 \%$ is the average for the branches).

Regarding to the problem Weak market the companies from the agriculture sector are differing from the most for lack of complains. Regarding to the Communication with the local administration practically the only complains are coming from company of the Producing Industry.

And at last, the companies from agriculture in the biggest percentage (70) claim that they 
MANOLOVT.

have no problems on a local level, but only such on a national level. The smallest share for this statement consists from companies from Agriculture and from the Gaining Industry (respectively 25 and $16 \%$ ).

Table 13. Cross-table: branches / willingness for removing

\begin{tabular}{|c|c|c|c|c|c|}
\hline \multirow[b]{2}{*}{ Branch } & \multicolumn{4}{|c|}{ Willingness for removing } & \multirow[b]{2}{*}{ Total } \\
\hline & Rather Yes & Rather No & $\begin{array}{c}\text { Possibility for } \\
\text { a branch }\end{array}$ & $\begin{array}{l}\text { Possible } \\
\text { closure }\end{array}$ & \\
\hline \multirow{4}{*}{ A } & 2 & 13 & 1 & 0 & 16 \\
\hline & $12,50 \%$ & $81,25 \%$ & $6,25 \%$ & $0,00 \%$ & $100,00 \%$ \\
\hline & $40,00 \%$ & $10,83 \%$ & $4,76 \%$ & $0,00 \%$ & $10,74 \%$ \\
\hline & $1,34 \%$ & $8,72 \%$ & $0,67 \%$ & $0,00 \%$ & $10,74 \%$ \\
\hline \multirow{4}{*}{ B } & 1 & 4 & 1 & 0 & 6 \\
\hline & $16,67 \%$ & $66,67 \%$ & $16,67 \%$ & $0,00 \%$ & $100,00 \%$ \\
\hline & $20,00 \%$ & $3,33 \%$ & $4,76 \%$ & $0,00 \%$ & $4,03 \%$ \\
\hline & $0,67 \%$ & $2,68 \%$ & $0,67 \%$ & $0,00 \%$ & $4,03 \%$ \\
\hline \multirow{4}{*}{$\mathrm{C}$} & 0 & 39 & 15 & 2 & 56 \\
\hline &, $00 \%$ & $69,64 \%$ & $26,79 \%$ & $3,57 \%$ & $100,00 \%$ \\
\hline &, $00 \%$ & $32,50 \%$ & $71,43 \%$ & $66,67 \%$ & $37,58 \%$ \\
\hline &, $00 \%$ & $26,17 \%$ & $10,07 \%$ & $1,34 \%$ & $37,58 \%$ \\
\hline \multirow{4}{*}{$\mathrm{D}$} & 0 & 2 & 0 & 0 & 2 \\
\hline & $0,00 \%$ & $100,00 \%$ & $0,00 \%$ & $0,00 \%$ & $100,00 \%$ \\
\hline & $0,00 \%$ & $1,67 \%$ & $0,00 \%$ & $0,00 \%$ & $1,34 \%$ \\
\hline & $0,00 \%$ & $1,34 \%$ & $0,00 \%$ & $0,00 \%$ & $1,34 \%$ \\
\hline \multirow{4}{*}{$\mathrm{F}$} & 1 & 8 & 1 & 0 & 10 \\
\hline & $10,00 \%$ & $80,00 \%$ & $10,00 \%$ & $0,00 \%$ & $100,00 \%$ \\
\hline & $20,00 \%$ & $6,67 \%$ & $4,76 \%$ & $0,00 \%$ & $6,71 \%$ \\
\hline & $0,67 \%$ & $5,37 \%$ & $0,67 \%$ & $0,00 \%$ & $6,71 \%$ \\
\hline \multirow{4}{*}{ G } & 1 & 34 & 3 & 1 & 39 \\
\hline & $2,56 \%$ & $87,18 \%$ & $7,69 \%$ & $2,56 \%$ & $100,00 \%$ \\
\hline & $20,00 \%$ & $28,33 \%$ & $14,29 \%$ & $33,33 \%$ & $26,17 \%$ \\
\hline & $0,67 \%$ & $22,82 \%$ & $2,01 \%$ & $0,67 \%$ & $26,17 \%$ \\
\hline \multirow{4}{*}{$\mathrm{H}$} & 0 & 4 & 0 & 0 & 4 \\
\hline & $0,00 \%$ & $100,00 \%$ & $0,00 \%$ & $0,00 \%$ & $100,00 \%$ \\
\hline & $0,00 \%$ & $3,33 \%$ & $0,00 \%$ & $0,00 \%$ & $2,68 \%$ \\
\hline & $0,00 \%$ & $2,68 \%$ & $0,00 \%$ & $0,00 \%$ & $2,68 \%$ \\
\hline \multirow{4}{*}{ I } & 0 & 7 & 0 & 0 & 7 \\
\hline & $0,00 \%$ & $100,00 \%$ & $0,00 \%$ & $0,00 \%$ & $100,00 \%$ \\
\hline & $0,00 \%$ & $5,83 \%$ & $0,00 \%$ & $0,00 \%$ & $4,70 \%$ \\
\hline & $0,00 \%$ & $4,70 \%$ & $0,00 \%$ & $0,00 \%$ & $4,70 \%$ \\
\hline \multirow{4}{*}{$\mathrm{J}$} & 0 & 4 & 0 & 0 & 4 \\
\hline & $0,00 \%$ & $100,00 \%$ & $0,00 \%$ & $0,00 \%$ & $100,00 \%$ \\
\hline & $0,00 \%$ & $3,33 \%$ & $0,00 \%$ & $0,00 \%$ & $2,68 \%$ \\
\hline & $0,00 \%$ & $2,68 \%$ & $0,00 \%$ & $0,00 \%$ & $2,68 \%$ \\
\hline \multirow{4}{*}{$\mathrm{L}$} & 0 & 1 & 0 & 0 & 1 \\
\hline & $0,00 \%$ & $100,00 \%$ & $0,00 \%$ & $0,00 \%$ & $100,00 \%$ \\
\hline & $0,00 \%$ & $0,83 \%$ & $0,00 \%$ & $0,00 \%$ & ,67\% \\
\hline & $0,00 \%$ & $0,67 \%$ & $0,00 \%$ & $0,00 \%$ & ,67\% \\
\hline \multirow{4}{*}{ M } & 0 & 2 & 0 & 0 & 2,00 \\
\hline & $0,00 \%$ & $100,00 \%$ & $0,00 \%$ & $0,00 \%$ & $100,00 \%$ \\
\hline & $0,00 \%$ & $1,67 \%$ & $0,00 \%$ & $0,00 \%$ & $1,34 \%$ \\
\hline & $0,00 \%$ & $1,34 \%$ & $0,00 \%$ & $0,00 \%$ & $1,34 \%$ \\
\hline \multirow{4}{*}{ Other } & 0 & 1 & 0 & 0 & 1 \\
\hline & $0,00 \%$ & $100,00 \%$ & $0,00 \%$ & $0,00 \%$ & $100,00 \%$ \\
\hline & $0,00 \%$ & $0,83 \%$ & $0,00 \%$ & $0,00 \%$ & $0,67 \%$ \\
\hline & $0,00 \%$ & $0,67 \%$ & $0,00 \%$ & $0,00 \%$ & $0,67 \%$ \\
\hline \multirow{4}{*}{ Total } & 5 & 120 & 21 & 3 & 149 \\
\hline & $3,36 \%$ & $80,54 \%$ & $14,09 \%$ & $2,01 \%$ & $100,00 \%$ \\
\hline & $100,00 \%$ & $100,00 \%$ & $100,00 \%$ & $100,00 \%$ & $100,00 \%$ \\
\hline & $3,36 \%$ & $80,54 \%$ & $14,09 \%$ & $2,01 \%$ & $100,00 \%$ \\
\hline
\end{tabular}




\section{CONCLUSION}

Relations between the companies' economic results and their contentment of their localization:

$\checkmark$ There isn't an expressed relation between the companies' economic result (profit, loses) for the last years and their contentment of their localization;

$\checkmark$ The hypothesis for possible relation between the economic result of the companies and their willingness for removing in another region is also tested, although of such initial assumption. Again such relation cannot be seen;

$\checkmark$ The only obvious relation relates to the companies which declared loses for 2010. For them the problem with "weak market" is expressed with higher than the average rate of a statistically significant value.

Relations between the size of the company (number of employees ) and their attitude towards the localization.

* There isn't a relation between the size of the company and its contentment of the localization;

* Low willingness for removing could be seen only among the micro and small sized companies ( 3 to $5 \%$ );

Soundly willingness for establishing new branches could be found among the big companies - $33 \%$ - this willingness is almost unnoticeable among the small companies $-5 \%$;

* Regarding to the PROBLEMS WITH THE LOCALIZATION: The big and the medium sized companies pointed out as a factor the "unattractiveness of the sector", but on the other side they have no inconveniences concerning the problem "weak market";

\section{REFERENCES}

1. Armstrong H., Taylor J., Regional Economics and Policy, 3rd edn. London, Blackwell, 2000

2. Cécora,J, Cultivating Grass-Roots for Regional Development in a Globalizing Economy - Innovation and entrepreneurship in organized markets Ashgate, Aldershot, 1999

3. Foundation "European Institute", "Structural Funds of the European Union. How to succeed? ", Sofia, NIBA Consult, 2007

4. Hildebrand, G., and Mace, A., 1950, The employment multiplier in an expanding industrial market: Los Angeles County, 1940-47, Review of Economics and Statistics, vol.32, no.3

5. NSI, Final counting data, Sofia, 2011

6. Williams R., Keywords, Harper Collins, London, 1983 